\title{
The Principles of Scientific Management Spread Forever---- to Commemorate the Principles of Scientific Management Be Published by the 100th Anniversary
}

\author{
Yangfei Zhang \\ Department of commerce, Tianjin university of commerce, Tianjin ,300134,China
}

\begin{abstract}
The publication of the principles of scientific management made the human's management by science instead of experience. The ideas of scientific management have been spread and used widely in the world for 100 years, giving a specified direction for the emergence and development of management theory. Its application improved the efficiency of the prevailing labor and management efficiency, and always affects the human management practices. This paper will summarize and analyze five main contents and the six core principles of the scientific management.
\end{abstract}

Keywords-work quota; standardization; psychological revolution; difference piecework

\section{INTRODUCTION}

Late 19th and early 20th century, the capitalist countries facing an unprecedented economic crisis, and Taylor, who is committed to improving labor productivity, is published the Principles of scientific Management in 1911. The published of the book caused all the attention and study immediately in the United States, and also it has opponents, but Taylor and his followers make unremitting efforts for the spread and development of scientific management principles. Principles of scientific management have had a tremendous impact for the United States, France, Germany, Italy, Sweden, the Netherlands, Japan, the former Soviet Union, China and other countries, and now, Principles of scientific Management will continue to play its due role, will make perpetual contribution for the whole development of the world and human development.

\section{FIVE MAIN CONTENTS OF THE PRINCIPLES OF SCIENTIFIC MANAGEMENT}

The second half of the 19th century, the capitalist countries has embarked on a path of industrialization. To the early 20th century, western society has experienced the worldwide economic crisis five times, and the United States as the representative of the whole of Western society is in a very contradictory social status: on the one hand, the rapid rise of large industrial enterprises and the sharp increase in market demand for commodities; on the other hand, employers and managers uncultured management methods, which making labor too long, the intensity is too large and efficient and wages are too low, lead employers and workers contradiction between the increasingly frequent and intense. [1] In order to solve these social contradictions, it is urgent need for a new management theories and methods.
Frederick Winslow Taylor was such a person, who known as the "father of scientific management" after died; impacted on the assembly line production, is an admirer of Lenin, impacted on the industrialization process of the human person; criticized by modern management scholars. [2] Frederick Winslow Taylor (1856-1915) is the most important and also the most controversial person in the history of ideas on the management, from 1881 onwards, he began to work for workers study, after ten years, published the Principles of scientific Management in 1911 and proposed the idea of scientific management. Prior to this, the studies on management is so mush, such as the British economist Adam Smith proposed the idea of division of labor, then British economist Charles Babbage developed Smith's view and proposed salary plus bonus reward system, and gives some suggestions on scientific management. But they can not form a scientific system in the management, but have their own unique views on it at some point. The Principles of scientific Management based on the results of previous studies, together with its own experimental study hard, and finally formed a relatively systematic scientific management theory, so that make manage according to experience to a real science. The Principles of scientific Management's published, greatly impacted on the political, economic, educational, cultural and other aspects of USA, and was popular in Europe in 1913, then spread to Russia. Such a system make the labor of production rationalization, thus it has played a significant role for accelerating the industrialization process of capitalist countries.

\section{THE PRINCIPLES OF SCIENTIFIC MANAGEMENT}

The principles of scientific management is a scientific method of introducing the writings of management practices, it makes the experience to manage the human sciences. Principles of scientific management essentials epitomized:

\section{A. The principle of work quota}

To determine the work quota scientific research process is used Taylor: first, choose the appropriate and skilled workers; second, research the exact sequence of these people use in their work basic operations or actions, and each person uses tools; third, action to eliminate all errors, ineffective action, improved irrational action, which selected aspects of the work necessary for each action; fourth, with a stopwatch recorded the time required for each basic action, plus necessary rest time and delay time to determine labor per unit of product needed to complete; fifth, with the daily working hours required per unit of 
product divided by the labor time, you can get a "reasonable daily workload." Taylor said: work quota should select the highest workload of workers, but not selected in the middle to upper workload sometimes, this "reasonable daily workload," should be "first-class workers to maintain, without prejudice to their health longer time speed "as the standard.

\section{B. Standardization principle}

Taylor said: workers has very large potentiality to raise labor productivity. We should summarize and organize the experience accumulated over the years and the traditional skills, and find out the regularity of things, standardize them and form a scientific approach.

\section{C. "First-class workers" advanced ideas}

Taylor said: any worker can become a "first-class workers". "first-class workers" depends on two critical: firstly, whether the worker is willing to become a "first-class worker"; secondly, whether workers get the necessary training. The two key, is to create "first-class worker" the perfect combination of subjective and objective conditions. Taylor emphasized: To play the greatest ability of workers to be the right choice for workers, creating a "first-class" team of workers; make excellent workers into the ranks must be vocational training; training must be done by qualified teachers - administrators carried out with a new method of operation through scientific analysis and design training workers out until the workers have to work until the scientific laws; workers are not suitable for those working and should be trained to fit operational needs, or rearrange them to other suitable jobs go. Taylor firmly believes: training workers to become first-class workers, leadership responsibilities.

\section{Difference piecework system}

Taylor cited four wage system in his book: the timing system, piece-rate system, the task with bonus system and differential piecework system, which is more focused by Taylor. As early as 1895, he proposed a "differential piecework system," which introduced to his thought, Its main contents are developing a science-based quota system standard and using different wage rates according to workers completed the fixed or not. If workers completed over a fixed amount, it would unpaid by the high rate of unpaid wages. If workers did not reach the quota, it would paid by low wage rates.

\section{E. Separation of planning and implementation functions}

Taylor said: the rational division of planning functions and executive functions is a scientific method of work. Taylor advocated the creation of specialized planning department, whose functions are engaged in research, providing scientific basis for fixed and operating methods, developing science-based quotas and standardized operating methods and tools, developing plans. Workers or foremen are engaged in executive functions, who use a predetermined standard tools all in accordance with the instructions of the planning department. This is actually the beginning of management specialization.

\section{F. Exception to the principle}

Taylor said: a large-scale enterprise must be managed using the exception to the principle, Enterprise senior management should be delegated to the general daily affairs subordinate managers to handle and be responsible for, but they only retain decision-making power, control and oversight powers to exceptions, which do not always happen, no prior experience to draw on and will have a significant impact on business if dispose of properly. Therefore, senior leaders should focus attention on the exceptions. this idea is the source of modern theories of decentralization, which provides the basic ideas for the future of the principle of separation of powers and organizational structure of the division system in the form of design management.

To sum up, the areas of principles of scientific management is throughout the whole process of management. Here is its greatness.

First, the "principles of scientific management" was the first great milestone management. Its publishing made the management from experience to science. Work quota principle provides scientific work standards. Standardization principle provides objective conditions for workers to complete high standards of work quota. The different piecework is incentive and punitive measures, which measure workers completed or not. Separation of planning and executive functions made management embark on a path of specialization. Exception principles are the basic principles of management established for senior managers. This eight content, interrelated, interdependent, mutual restraint, is strict logic, forming a more scientific system.

Second, the "principles of scientific management" is the cornerstone of management science, which pointed out the direction for future to research management and was the starting point for the development of modern management science. For example, U.S. HL Gantt think the different piecework system can't achieve the cooperation between workers and managers, who proposed a set of "task and bonus system," HL Gantt invented the Gantt chart when recording the workers complete the work quota or not. H. Fayol divided management functions and proposed 14 management principles. On the basis of separation of planning and execution functions, Max Weber proposed the "ideal system of administrative organization" theory.

\section{BENEFIT IN THE CONTEMPORARY}

Since the birth of scientific management, it was opposed by traditional management thinking. Later, scientific management principles aroused extensive discussions through several hearings in the U.S. Congress by Taylor and giving different aspects of improvement and dissemination research by some of Taylor's followers 。 There is a large-scale scientific management movement in the United States, regardless of the business community, education or government agencies. The U.S. labor 
productivity was increased by 2-3 times. The income of workers was increased by $30-100 \%$. Companies were keeping a low production cost and no strike occurs. [4] Overall, the real wages has doubled from 1890 to 1921 , average weekly working hours from 60 hours down to 50 hours. In the decade 1919-1929, labor efficiency increased by $43 \%$.[5]

Principles of scientific management soon spread abroad. Principles of scientific Management had a tremendous impact to management in many countries such as France, Germany, Italy, Sweden, the Netherlands, Japan and the former Soviet Union, China. Since using the scientific management, the productivity of all the advanced countries was improved by about 50 times. On such an unprecedented expansion, the developed countries has improved the standard of living and quality of life[3]. Japan is the first country time to promoting scientific management. In 1912 or 1913, Taylor's writings appeared, and scientific management ideas spread quickly in Japan. Many studies have established the Institute of Taylor. Taylor's Management thinking was widely used in Japanese industrial enterprises, thus contributing to the transition from an agricultural country to the Japanese industrial countries.

\section{V.BENEFIT FUTURE GENERATIONS}

Taylor proposed principles of scientific management after personally tests and careful study. Its scientific, groundbreaking and guidance were unquestioned, management thought the latter were mostly evolved developed from the principles of scientific management. As well-known management expert Ewei Ke said: Many current so-called modern management methods can be traced back at least half a century, Taylor and his followers thought previously proposed." Although these management methods have been improved and developed almost unrecognizable with the original, but the core idea can usually be found in Taylor's writings and practice.
Looking at the social reality, due to intense competition, people specially emphasis on competition, which is certainly necessary, but we can't ignore the spirit of cooperation. To achieve a win-win or win, psychological revolution and the changing role of the manager is particularly important in the competition. Enterprises in order to motivate workers to work better, a variety of benefits, annual bonuses and other compensation system came into being. The difference piecework system becomes even more incentive effect after development. In the case of the rapid development of science and technology, production machinery instead of manual labor, the application of the principles of standardization will become increasingly common, as far as possible to expand production to meet social needs.

The development of the times made employees become knowledgeable staff increasingly. Along with the work continues to expand and enrich the content, the difference between planning and execution was progressive blurred. With increased mechanization and automation, organizations must be able to require employees to engage in the planning of the work, not just bow down.

Despite its limitations, but with the rapid development of technology, scientific management principles are still shining with the glory, full of boundless vitality, and continue benefit for all mankind! Great father of scientific management, Frederick Winslow Taylor, will be immortal!

\section{REFERENCES}

[1] Ross $\bullet$ M $\bullet$ Robertson. American Economic History (third edition). New York: Harcourt Brace • Jovanović Publishing Company, 1973.

[2] Frederick Taylor. Principles of Scientific Management. Beijing: Mechanical Industry Press, 2007.

[3] Frederick Taylor. Testimony in the U.S. Congress. Beijing: China Social Sciences Press, 1984.

[4] Guo-zhi Sun. Taylor's Scientific Management Theory. Legal System and Society, (3), pp722, 2007.

[5] Yong-min Wang. Further Discussion of Taylor's essence of management thinking. The Journal of Sun Yat-sen University, (2). pp46, 2005. 